\title{
Infant formula safety concerns and consequences in China
}

\author{
Ai-Ling Ji, Yin-Ling Irene Wong, Tong-Jian Cai, Jianghong Liu \\ Xi'an, China
}

$\mathrm{F}$ ood safety is an important public health problem for the entire world, especially developing countries. Food safety incidents in China in the recent years have threatened the health of the Chinese citizens. ${ }^{[1]}$ Many products, including chicken, pork, beef and rice and so on, were found to be unsafe for consumption. Vegetables tainted with pesticides, pork tainted with clenbuterol, fish treated with cancer-causing antimicrobials, eggs colored with industrial dye, fake liquor that could induce blindness or death, exploding watermelons, and recycled "drainage oil" containing carcinogens and traces of aflatoxin have been put on the people's daily dining table. ${ }^{[2,3]}$ The outcome was outrage across the country. Public confidence in the food industry plummeted. People turned pale at the mention of "food". Some people even started to plant vegetables in their own house. ${ }^{[4]}$

In all these incidents, the most cases with the most cause for concern are those involving infant formula foods. Almost 10 years ago, there was a milk incident at Fuyang, Anhui Province. At least 13 infants were dead due to ingesting the fake infant formula that was short of nutrients. ${ }^{[5]}$ At that time, more than 20 persons were sentenced to serve in prison for periods varying from 6 months to 8 years. ${ }^{[6]}$ Four years later, a even more serious scandal involving infant formula broke out. In 2008, the famous "Sanlu" branded baby formula was found to contain high concentrations of melamine, a

\footnotetext{
Author Affiliations: Department of Nutrition \& Food Hygiene and the Ministry of Education Key Lab of Hazard Assessment and Control in Special Operational Environment (Ji AL), Department of Occupational \& Environmental Health (Cai TJ), School of Public Health, Fourth Military Medical University, Xi'an 710032, China; School of Nursing, University of Pennsylvania, Philadelphia, PA 19104, USA (Ji AL, Liu J); School of Social Policy \& Practice, University of Pennsylvania, Philadelphia, PA 19104, USA (Wong YLI)

Corresponding Author: Jianghong Liu, PhD, Schools of Nursing and Medicine, University of Pennsylvania, 418 Curie Blvd., Room 426, Claire M. Fagin Hall, Philadelphia, PA 19104-6096, USA (Tel: 215-898-8293; Email: jhliu@nursing.upenn.edu)

doi: 10.1007/s12519-014-0447-3

(C)Children's Hospital, Zhejiang University School of Medicine, China and Springer-Verlag Berlin Heidelberg 2014. All rights reserved.
}

chemical that can cause serious lithiasis in the urinary system. According to the official Chinese data submitted to the World Health Organization, the maximum concentration of melamine in Sanlu's baby formula was as high as $4700 \mathrm{mg} / \mathrm{kg}^{[7]}$ while the safe limit released later was $1.0 \mathrm{mg} / \mathrm{kg}$. Many other well-known brands were also found to have the same problem. It has been reported that about 300000 babies became ill, with at least six deaths, due to the formation of kidney stones and other complications caused by toxic baby formulas ${ }^{[8]}$ Even after these issues came to light, infant formulas with numerous health problems continued to be discovered. In 2011, a large milk producer said that excessive toxin levels had been found in its milk because of moldy cattle feed. In 2012, another large producer recalled formula tainted with mercury. ${ }^{[9]}$ These incidents have understandably provoked nationwide panic among Chinese parents. Because of worrying about the safety of Chinese milk powders, they are now buying up infant milk powder everywhere outside of China that they can get it. ${ }^{[10]}$

On March 1, 2013, the Hong Kong government carried out the revised Import and Export Regulations policy, which includes a specific provision for the allowed quantity of baby formula powder for children less than 36 months of age. This provision was written because infant formula was in short supply in some areas of Hong Kong. ${ }^{[11]}$ According to this provision, a person at least 16 years of age can only carry up to two cans, or $1.8 \mathrm{~kg}$ (about $3.97 \mathrm{lbs}$.), of baby formula out of Hong Kong. Violators may face fines of up to HK\$500 000 (about \$64 500) and up to two years in jail. ${ }^{[12]}$ On March 2, 25 people had already been arrested for attempting to take baby formula powder beyond the specified limit outside the borders of Hong Kong. Since then, even more people have been arrested, and the total number of these arrested milk powder "smugglers" reportedly exceeded the number of heroin carriers detained at the border of Hong Kong in 2012. On March 6, Liang Zhenying, Chief Executive of Hong Kong Special Administrative Region, stated that the deficient infant formula powder supply in Hong Kong had been corrected. ${ }^{[13]}$ Due to the stringent restrictions, the sales volume of baby formulas in Hong Kong plummeted significantly only two months after the regulation was implemented. ${ }^{[14]}$ On September 24, Mr. Gao Yongwen, 
Table. New and revised food safety regulations implemented since 2009

\begin{tabular}{|c|c|}
\hline Time & Regulations \\
\hline June 1, 2009 & Food Safety Law of the People's Republic of China \\
\hline July 20, 2009 & People's Republic of China Food Safety Law Implementation Rules \\
\hline February 10,2010 & State Council Food Safety Commission was set up \\
\hline May 1, 2010 & The Measures for the Supervision and Administration of Food Safety in Catering Services \\
\hline December 1, 2010 & $\begin{array}{l}\text { National Food Safety Standard Good Manufacturing Practice for Powdered Formulae for Infants and Young Children (GB } \\
\text { 23790-2010) }\end{array}$ \\
\hline May 1,2010 & Administrative Measures for the Licensing of Catering Services \\
\hline April 1, 2011 & National Food Safety Standard Infant Formula (GB 10765-2010) \\
\hline April 1, 2011 & National Food Safety Standard Older Infants and Yong Children Formula (GB 10767-2010) \\
\hline August 22, 2011 & Operating Specifications on Food Safety in Catering Services \\
\hline June 1, 2011 & Administrative Measures on Inspection and Quarantine of Import and Export Meat Product \\
\hline June 1, 2011 & Measures for the Supervision and Administration of Inspection and Quarantine of Imported and Exported Aquatic Products \\
\hline June 20, 2011 & Hygienic Standards for Uses of Food Additives (2760-2011) \\
\hline January 1,2012 & The National Food Safety Standards of Special Medical Use Infant Formula Food Rules (GB 25596-2010) \\
\hline April 20, 2012 & General Standard for the Labeling of Prepackaged Foods (GB7718-2011) \\
\hline March 1, 2013 & Maximum Residue Limits of Pesticides in Food \\
\hline
\end{tabular}

chief of the Hong Kong Food and Health Bureau, declared that the Hong Kong government would soon begin stress tests on the city's supplies of baby formula on the National Day holiday on October $1 .^{[15]}$ The results of the tests would determine whether the restrictions on mainland purchases could be lifted within a short time. This caused Hong Kong mothers grow concerned at the possibility of outside buyers again depleting the Hong Kong supply of baby formula. The later declaration released October 13, 2013 suggested that previously declared limit would not be lifted in the near future. ${ }^{[16]}$

In response to the problems of toxic and unsafe food, the Chinese Government has taken a series of measures to manage the situation for food in general and baby formula. In 2009, the new food safety law went into effect and the State Council Food Safety Commission, composing of three vice premiers and more minister-level officials, was established in 2010 to help enforce it. The new specified standards for infant formula are listed in the Table. The Chinese government also enforced much stricter regulations, as evidenced by the large number of food safety cases brought to the judicial system. Additionally, the local government in Hohhot has decided to set up a national laboratory to monitor products of Mengniu and Yili, China's two dairy giants. Furthermore, the government will increase investment and encourage private capital in building grazing land and dairy farms to ensure milk quality from the source. ${ }^{[17]}$

More recently in March 2013, a new ministry-level administration, the General Administration of Food and Drug, was established in order to boost people's confidence in the quality of the nation's food. This new administration replaced the old State Food and Drug Administration and is responsible for supervising food and drug safety during processes of production, circulation and consumption. Additionally, the new national health and family planning commission is now responsible for assessing food safety risks and formulating food safety standards ${ }^{[18]}$ It is only with strict, ongoing oversight and swift response that the Chinese food industry can begin to regain the trust of the Chinese people.

People often view food and diet as essential needs, and place food safety as a top priority. However, there is dissatisfaction in the Chinese people given the current situation of food safety. There are several causes for the emerging food contamination. Firstly, environmental pollution, including air, water and soil pollution, is an increasing problem in China. With the pollution in the environment becoming more and more serious, the probability of the pollutants entering foods also increase, thereby raising concerns over food safety. ${ }^{[19]}$ Secondly, the management of the food market in China needs to be further improved. For example, in many Chinese cities, food sales are always conducted through roadside markets, most of which have inadequate labeling on foods and lack information on potential risk factors, which can lead to decreased consumer confidence. ${ }^{[20]}$ The core problems for achieving food safety in China, however, are interest and responsibility of the government. Measures should be implemented to ensure the safety of the food. The government has carried out many regulations, but in the future, relevant governmental departments, merchants companies, and all of us should collaborate in order to implement the regulations more strictly and thoroughly to ensure food safety in China.

Funding: This study was in part supported by National Institutes of Health/National Institute of Environmental Health Sciences 
USA (NIH/NIEHS) 1K02ES019878 to Liu J.

Ethical approval: The authors have no financial relationships relevant to this article to disclose.

Competing interest: The authors have no conflicts of interest to disclose.

Contributors: JAL wrote the first draft of this paper. All authors contributed to the intellectual content and approved the final version. $\mathrm{LJ}$ is the guarantor.

\section{References}

1 Xinhua News, 2006. http://news.xinhuanet.com/food/200609/07/content_5062333.htm (accessed October 1, 2013).

2 China Daily USA, 2013. http://usa.chinadaily.com.cn/life/201303/18/content 16319697.htm (accessed October 1 2013).

3 Xinhua News, 2011 http://news.xinhuanet.com/english2010/ indepth/2011-09/14/c 131138369.htm (accessed October 1, 2013).

4 Xinhua News, 2013. http://news.xinhuanet.com/ fortune/2013-08/24/c_117075987.htm (accessed October 1, 2013).

5 BBC News, 2004. http://news.bbc.co.uk/2/hi/asiapacific/3648583.stm (accessed October 1, 2013).

6 People's Daily, 2004. http://www.people.com.cn/GB/ shehui/1061/3033167.html (accessed October 1, 2013).

7 WHO, 2008. http://www.who.int/entity/foodsafety/fs management/Melamine.pdf (accessed October 1, 2013).

8 CNN, 2008. http://www.cnn.com/2008/WORLD/asiapcf/12/30/ china.sanlu/ (accessed October 1, 2013).

9 Bloomberg Businessweek, 2013. http://www.businessweek.com/ articles/2013-05-02/chinas-parents-crave-illegally-importedbaby-formula (accessed October 1, 2013).

10 The New York Times, 2013. http://www.nytimes. com/2013/07/26/world/asia/chinas-search-for-infant-formulagoes-global.html? $\mathrm{r}=0$ (accessed October 1, 2013).

11 Beijing News, 2013.http://news.xinhuanet.com/ gangao/2013-03/06/c_124420315_2.htm (accessed October 1, 2013).

12 China Daily, 2013. http://www.chinadaily.com.cn/ china/2013-03/04/content 16271673.htm (accessed October 1, 2013).

13 Xinhua News, 2013. http://news.xinhuanet.com/ gangao/2013-03/07/c_114918733.htm (accessed October 1, 2013).

14 China Economic, 2013. http://news.xinhuanet.com/ gangao/2013-04/30/c_124648649.htm (accessed October 1, 2013).

15 People's Daily, 2013. http://news.xinhuanet.com/ gangao/2013-09/25/c 125442926.htm (accessed October 1, 2013).

16 China International Broadcasting Network, 2013. http://news. xinhuanet.com/fortune/2013-10/13/c 125525848.htm (accessed October 10, 2013).

17 China Daily USA, 2013. http://usa.chinadaily.com.cn/ business/2013-03/08/content 16290752.htm Accessed May 15, 2013 (accessed October 1, 2013).

18 Xinhua News, 2013. http://news.xinhuanet.com/english/ china/2013-03/10/c_132221729.htm (accessed October 1, 2013).

19 The New York Times, 2013. http://www.nytimes. com/2013/12/31/world/asia/good-earth-no-more-soil-pollutionplagues-chinese-countryside.html?_r=0 (accessed December 30, 2013).

20 China daily, 2012. http://www.chinadaily.com.cn/hqgj/ jryw/2012-05-31/content_6059100_3.html (accessed May 1, 2013).

Received November 16, 2013 Accepted after revision January 6, 2014 